\title{
Geographical Economic Concentration, Growth and Decentralization: Empirical Evidence in Indonesia
}

\author{
Abd. Jamal \\ Faculty of Economics and Business, Syiah Kuala University, Banda Aceh - Indonesia \\ Corresponding Author: abdjamal@unsyiah.ac.id
}

Received: December 2016 | Revised: March 2017 | Accepted: October 2017

\begin{abstract}
This study aims to analyze the geographical economic concentration (GEC) in Aceh Province. The Decomposition AGC Index and secondary data for the period 2001-2014 are used in the analysis. The results showed that the GEC in Aceh Province tend to decline about -7.09 percents a year. Since 2011 the growth increased about 1.27 percent a year, but after two years it show the decline anymore. There are four phases of changes of GEC. Before the Aceh Province was proliferated from 13 to 23 districts, economic growth was not driving factor for economic concentration, but it become a driving factor after the proliferation. Government spending, both spatial and per capita are significant for economic concentration driver in Aceh-13, but in Aceh-23 they do not take a role anymore. In turn, population density is emerging in this period. The previous geographic economic concentration, apparently, as the most important factor in performing economic concentration.
\end{abstract}

Keywords: Geographical Economic Concentration, Government Spending, Population Density, Economic Growth

JEL Classifications: H72, R11, R12

How to cite: Jamal, A. (2017). Geographical Economic Concentration, Growth and Decentralization: Empirical Evidence in Aceh, Indonesia. Jurnal Ekonomi Pembangunan: Kajian Masalah Ekonomi dan Pembangunan, 18(2), 1-17. doi:https://doi.org/10.23917/jep.v18i2.2786

DOI: https://doi.org/10.23917/jep.v18i2.2786

\section{Introduction}

Economic growth commonly becomes the key of the development in underdeveloped countries. The high growth is believed to be able to improve the welfare of the nation as well as reduce disparities among population and minimize gaps among regions. Even disparities can occur among economic sectors in a region. Disparity is a scourge for development because it can lead to people's resistance against the state. This fact ever been occurred in Indonesia where the Aceh people resist on the Indonesian government by the Movement of Aceh Freedom (Gerakan Aceh Merdeka, GAM) for thirty years.
Disparities have become a sexy issue for some regions to force the central government to fulfill their needs. In fact, the issue of inequality encourages many regions to conduct the proliferation of region on the grounds of minimization of the gaps and improving the social welfare. In responding these issues, the government of Indonesia in New Order Regime (Orde Baru) developed the concept of growth-poles theory by developing the economic concentrations in certain region (Jamal, Muhammad, Masbar, \& Aliasuddin, 2015), and by assuming of trickledown effect. Growth-pole theory indicates the uneven development among regions, or 


\section{Jurnal Ekonomi Pembangunan, 18 (2), 2017, 142-158}

agglomeration tends to stand at certain location. Agglomeration economies push the geographical concentration of economic activities (Latzko, 2013). However, this policy did not provide the best solution, because the real trickledown effect did not occur. Otherwise, some economist declared as polarization was occurred (Vertakovaa, Polozhentseva, \& Klevtsova, 2015). Some studies showed the social polarization (MacLachlan \& Sawada, 1997; Rutkevich, 1994), political polarization (Hetherington \& Weiler, 2009; Grechyna, 2016), employment polarization (Waverman, 2015; Harper, Hibbard, Costa, \& Yeh, 2011) was occurred and created the spatial imbalances. Further, some of the facts indicate the existence of infrastructure polarization at specific location or region, which have an impact on economic polarization strengthening. Nevertheless, (Persky, Felsenstein, \& Carlson, 2004), suggested that trickle down, for a while is not negligible, remains limited.

The high economic growth leads to form the agglomeration which caused by circular relationship, where the spatial manufacture concentration creates and follows the market access (López-Rodríguez \& Faíña, 2007). Moreover, (O'Sullivan, 2007), explained that economic growth can be sourced from nongeographical traditional economic growth, namely, capital deepening, human capital improvement, technological progress, and geographical source of economic growth that is agglomeration economies. Agglomeration at certain location encourages a high economic growth, thus, becoming an urban area or developed region. The agglomeration exists when spatial concentration one or more economic activities generate the market sizes (Clipa, Pohoață, \& Clipa, 2012), and thus, encourage the development of further (or new) concentration of industries. Hence, efficiency is increased from this agglomeration linked with local pooled labor market (Ascani, Crescenzi, \& Iammarin, 2012).
Agglomeration

(or

geographical concentration) of economic activities accompanied by knowledge spillover where both are mutually reinforcing will provide dynamic impetus for regional growth (Alexiadis, 2013). Moreover (Fujita \& Thisse, 2002) argued that growth and agglomeration can go hand in hand, more specifically, when the economy moves from dispersion to agglomeration, innovation follows faster. This means that the agglomerated region has a high economic growth due to the development of economic activities. Further, some researchers (Talmaciu, 2012; Berea, Otoiu, \& Bucerzan, 2014) said that innovation represent determinant factor of economic growth, rather than traditional factors. The $R \& D$ expenditures promote the economic growth, while population does not always relate to economic growth, especially in capital intensive. Conversely, unemployment alleviates economic growth.

Urban (or city) growth has strong relationships with regional development. The city is an overview of the development of social institution, where technology and innovation are developed through interaction of market and nonmarket, so the city is regarded as the engine of growth (Duranton, 2008; McCann, 2001). A high growth of city as source of regional development is driven by specific sectors; such as industries, trade and services sector. However, the often problem in regional development is unbalance growth among sectors and among regions. Hypothesis of Kaldor's Engine of Growth (PonsNovell \& Viladecans-Marsal, 1999; Bautista, 2003; Cantore, Clara, \& Soare, 2014) and result of the study was conducted by some researchers such as (Szirmai \& Verspagen, 2010; Su \& Yao, 2016) suggested that manufacturing industry has a role as economic growth is positively correlated to urban concentration in developed country, but not in under-developed country. However, in some regions show the positive and negative correlation engine of growth in 
Jurnal Ekonomi Pembangunan, 18 (2), 2017, 142-158

developing countries. This indicates that a region with predominant in industrial sectors, so the region has rapid growth than others. In the case of Indonesia, Java is core of the economic development. Many industries concentrate or agglomerate in Java.

The data show that the economic activities concentrate in Java region by average of 57.22 percent of economic contribution, in period 20112015. While the Sumatra region that occupies in the second place, only manages around 39.93 percent of which are controlled by the Java. However, this condition is contrary to the economic growth of the regions. The higher economic growth regions give lower contribution to Indonesian economic, such as, Bali and Nusa Tenggara and also Maluku and Papua. Otherwise, Java and Sumatera region has a high role in the economy, but they have lower economic growth. This case indicates that economic concentration does not follow economic growth. The higher contribution of economic in Java is caused by the agglomeration of industries. Does political decentralization policy have correlation to geographical economic concentration in provincial region?

\subsection{Literature Review}

The study on economic concentration and growth has been analized by many researchers, such as (Chen, Zhang, Liu, \& Zhang, 2014; Castells-Quintana, 2015; Zheng \& Liu, 2010; Kim, 2008; Brülhart \& Sbergami, 2009), but they had different results each other.

The result of research conducted by (Chen, Zhang, Liu, \& Zhang, 2014) explained that urban concentration (or agglomeration) may promote economic growth, however, some other factors must be considered, such as geography, governmental management, history, culture, and institution setting, to explain among countries differences.

Meanwhile, (Castells-Quintana, 2015) found that economic growth is positively correlated to urban concentration in developed country, but not in under-developed country. However, by the regions show the positive and negative correlation. Furthermore, if the quality of urban infrastructure is considered, then it has positive correlation in country with high quality of infrastructure, otherwise negatively correlated. The relationship varies to depend on level of development and characteristics of the country.

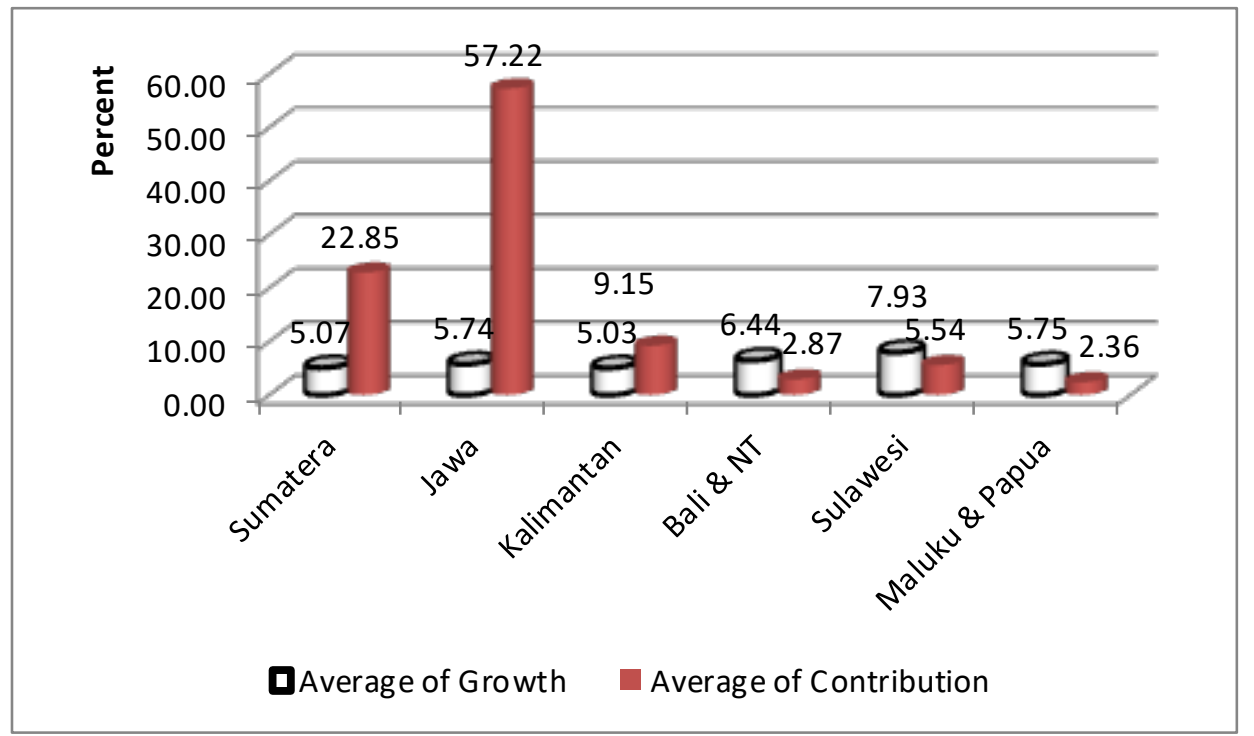

Source: BPS-Statistics Indonesia, 2016 (result of research)

Figure 1. Economic Growth and Economic Contribution 


\section{Jurnal Ekonomi Pembangunan, 18 (2), 2017, 142-158}

Even, level of sanitation has important role in developing country, where, in a country with low level of sanitation, then urban concentration is negatively correlated to economic growth.

But the result of research from (Zheng \& Liu, 2010) using Gini coefficient, it does not able to reveal the relation between economicconcentration with the local economic development. As a matter of fact, the development of construction industy encourages the development of all over industrial link, that drive to geographical concentration of construction industry. However, the study conducted by (Fana, Kanbur, \& Zhang, 2011) examined the evolution of regional disparities in China. In China's experience, the strategy of heavy industry development played an important role in forming of rural - urban disparities, while decentralization played a role in accelerating the inland - coastland disparities.

On the contrary, (Kim, 2008) explained that the main source of spatial inequality is driven by industrial geographic concentration differences, in developed country. Moreover, deconcentration of the population occured in Korea between 1970 to 1990, which was argued as caused by economic liberalization and massive investment in roads and communications. Nevertheless (Brülhart \& Sbergami, 2009) in their research conclude that spatial concentration at the level of whole countries, become progressively irrelevant, conversely, surpress the economic growth. But the result of research was conducted by (Fan \& Scott, 2003) concluded that the policy of central government planning in formation of industrial agglomeration succeeded to increase the economic performance in China. Meanwhile, the research was conducted by (Benedek, 2016) in Romania revealed that regional policies failed to reduce regional disparities, even, incompatibilities in the development of regions led to increase the polarization.

The study on decentralization and growth are also often examined by researchers. Many emperical studies suggest positive relationship between both variables, specially fiscal decentralization. However, some studies find that there is different effect on fiscal decentralization in many countries, although some studies that was conducted by (Akai, Nishimura, \& Sakata, 2007) concluded that fiscal decentralization policy, especially revenue decentralization is able to encourage economic growth, but the expenditure contributions have to be consistent with achieving the optimum economic growth, although some results show fiscal decentralization is not linear to economic performance, but depends on the structure of complementarity. Even, they examines that fiscal decentralization in CEE (Central and Eastern Europe) countries have negative sign to economic growth in periods 1990 - 2004. While the results of research in OECD countries carried out by (Bodman, 2011) showed that there is only a little evidence of the relationship between fiscal decentralization and economic growth. As well as (Dabla-Norris, 2006) in his research in Eastern Europe and Former Soviet Union concludes that there is no unique degree of decentalization that is suitable for all countries, but many factors determine the decentralization process. As well, the result of research examined by (Yushkov, 2015) in Russian experience, is concluded that expenditure decentralization has a negative relationship to regional economic development. On the contrary, the result of research studied by (Hammond \& Tosun, 2009) in United State counties suggest that fiscal decentralization supports long-run economic growth. Heterogeinity has a role in impact of fiscal decentralization on economic indicators, and the growth affect of fiscal decentralization differs across regions.

\section{Methods and Data}

This research analyzes the relationship of decentralization policy, geo-economic concentration and economic growth. The study is conducted in Aceh Province is caused by three reasons. First, the region was ever evolving as one of the centers of large-scale industries in Indonesia, which encouraged the formation of regional economic growth centers. Second, Aceh 
Province was ever been a conflict area, so central government enacted political policy through the Act of Republic of Indonesia Number 11/2006 on the Government of Aceh as Special Autonomous Region. The third, the political policy of decentralization which was enacted nationally has led to the proliferation of the regions (province or district) in Indonesia, included some districts in Aceh Province.

The secondary data is used in this research from Indonesian Statistical Agency Publications and other related institutions. The data used covers 23 districts and cities in Aceh Province (map of Aceh Province as in appendix 1), in periods $2001-2014$.

$$
A G C=\sum_{i=1}^{N} \frac{y_{i}-p_{i}}{y_{i}-a_{i}}\left|y_{i}-a_{i}\right|+\sum_{i=1}^{N} \frac{p_{i}-a_{i}}{y_{i}-a_{i}}\left|y_{i}-a_{i}\right|
$$

The analysis model of Decomposition Adjusted Geographic Concentration (AGC) Index as development and adjustment of the limitation of Concentration Ratio, Herfindahl index, Ellison and Glaeser index (Ellison \& Glaeser, 1997) is used in this analysis as suggested by (Spiezia,
2002; OECD, 2003; Gardiner, Martin, \& Tyler, 2010).

Where: $y_{i}$ is the production share of district $\mathrm{i}, \mathrm{N}$ is the number of district, $\mathrm{p}_{\mathrm{i}}$ is the population share of district $i, a_{i}$ is the area of district $i$ as a percentage of the province area, and | | as the absolute value. This model is used to analyze the degree of geographical economic concentration. The use of this model in measuring the degree of geographical economic concentration is under consideration of the model has incorporated the broad of each area, while the others ignore this variable. It is also associated with the difference of potential economic and population among the regions. Thus, the measurement of the index has become smooth. The indices describes where the area or region that has the highest economic concentration. The higher index number indicates the higher concentration of economic geographically.

In analyzing the determinant factors of geographical economic concentration, panel data regression (Gujarati, 2011) is used and formulated as:

$$
\mathrm{GEC}_{\text {it }}=\beta_{0}+\beta_{1} \mathrm{POPD}_{\mathrm{it}}+\beta_{2} \mathrm{GECAP}_{\mathrm{it}}+\beta_{3} \mathrm{SPAGE}_{\mathrm{it}}+\beta_{4} \mathrm{GR}_{\mathrm{it}}+\beta_{5} \mathrm{GEC}_{-1}+\varepsilon_{\mathrm{it}}
$$

Where: GEC, Geographical Economic Concentration Index; POPD as Population Density; GECAP, Direct Government Expenditure/Spending per capita; SPAGE, Spatial Government Expenditure/Government Expenditure Density; and GR as regional/district economic growth. In this regression analysis, data is divided to three groups, namely Aceh-13 for period 2001-2007, Aceh-13 for period 2001-2014 and Aceh-23 for period 2008-2014. The division is meant because of the completely proliferation of the districts in Aceh after 2007. In the period of 2001-2007 there were only 13 districts/cities in Aceh Province, however, since 2008 it becomes 23 districts/cities (see appendix 2).

Stochastic unit root test is used to prevent heterogeneity. The existing of unit root cause the regression specification affects the distribution of panel estimation asymptote (Levin, Lin, \& Chu, 2002). So, Levin-Lin-Chu (LLC) and Im-PesaranShin (IPS) test are used in unit root panel test. Unit root panel methods can improve potential panel heterogeneity (Im, Pesaran, \& Shin, 2003) which is caused by the differences of regional economic structure and regional growth path.

\section{Results and Discussion \\ 3.1 Geographical concentration shift}

The geographical economic concentration analyzed by using Decomposition AGC index in Province of Aceh Indonesia for period 2001 - 2013, in general indicated a declining trend (Figure 1). The sharp decline occurred in the period 2003 2010 , with average growth about -7.09 percent per year. The decline of indexes is accompanied 


\section{Jurnal Ekonomi Pembangunan, 18 (2), 2017, 142-158}

by increasing the amount of districts in Aceh. This indicates the economic concentration has spread and divided among districts, as well as, the declining of output entirety.

The declining of output was caused by some factors, that is, fact of the not conducive security in Aceh caused by vertical conflict between Freedom Aceh Movement (Gerakan Aceh Merdeka, GAM) against Indonesian Government (central government) was ongoing. Further, the tsunami disaster attacked Aceh Province in 2004 that destroyed all economic bases. Starts from 2011, the concentration indexes revive with the relative low growth, about 1.27 percent per year. But, in the next year, the index declined sharply by reaching of -12.99 percent. This means, during the research period, the geographical economic concentration in Aceh was hold deteriorating.

Since political reform in Indonesia, it has prompted the districts to make changes and efforts to minimize gaps among districts or regions. At the end of the New Order Regime (NOR), there was only one district is growing rapidly, namely North Aceh District. By no exception, Banda Aceh as the main city of Aceh Province was still lagging from. North Aceh District has enormous natural resources, especially oil and gas. These conditions made the region as an economic growth center in the Province of Aceh. So that, many population migrated or shifted to the region. As well, the downstream sectors interested and undertook the investment in the region. It encouraged the formation of economic concentration. Along with the time changes, in which natural resources owned is diminishing (non-renewable natural resources), coupled with the government's policies on regional (or district) proliferation, then the changes and the developments in the Aceh Province begin to shift.

In period 2001-2014, the geographical economic concentration in Aceh Province experienced several phases of changes (Figure 2, 3, 4 and 5). Since 2009, after the end of the rehabilitation and reconstruction programs of Aceh in the aftermath of the tsunami disaster, as well as the end of conflict between GAM against Indonesian Government, economic concentration occupies on two regions, namely, Lhokseumawe and Banda Aceh City. Even, in period 2010 - 2012, it has the same pattern of geographical economic concentration relatively, where Banda Aceh City has the highest index of economic concentration.

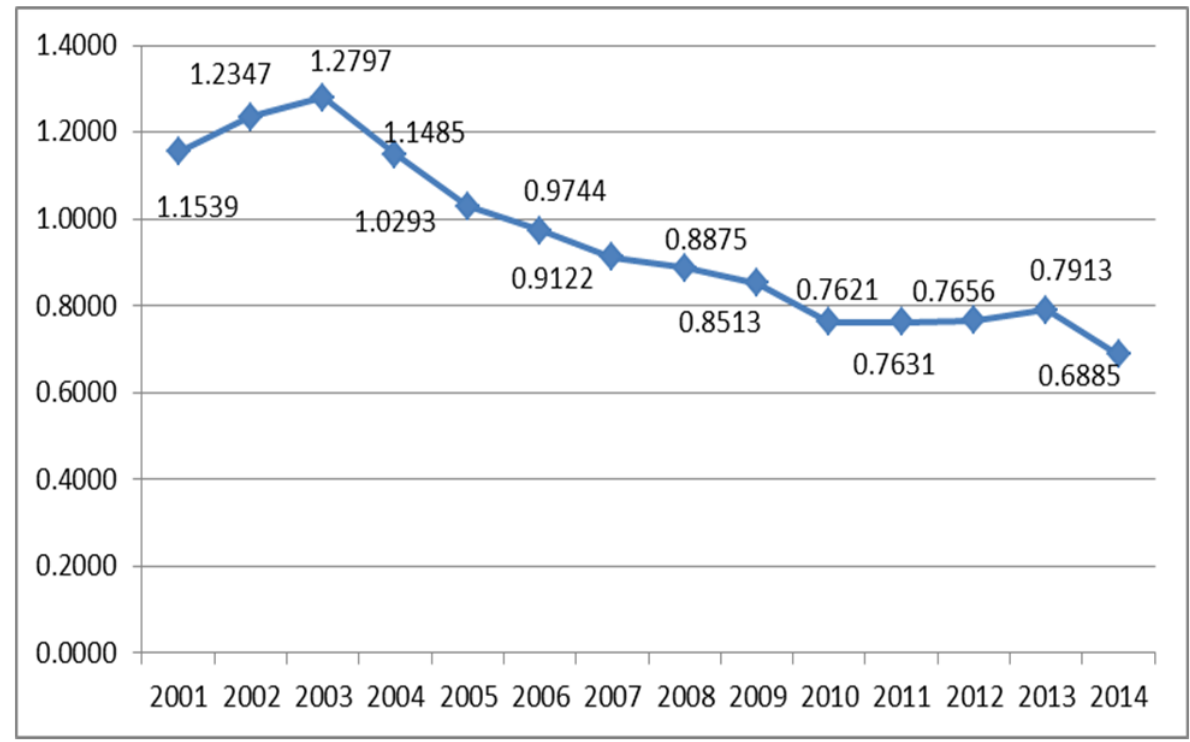

Source: Result of research (2016)

Figure:1.Geographical economic concentration index progress 
Jurnal Ekonomi Pembangunan, 18 (2), 2017, 142-158

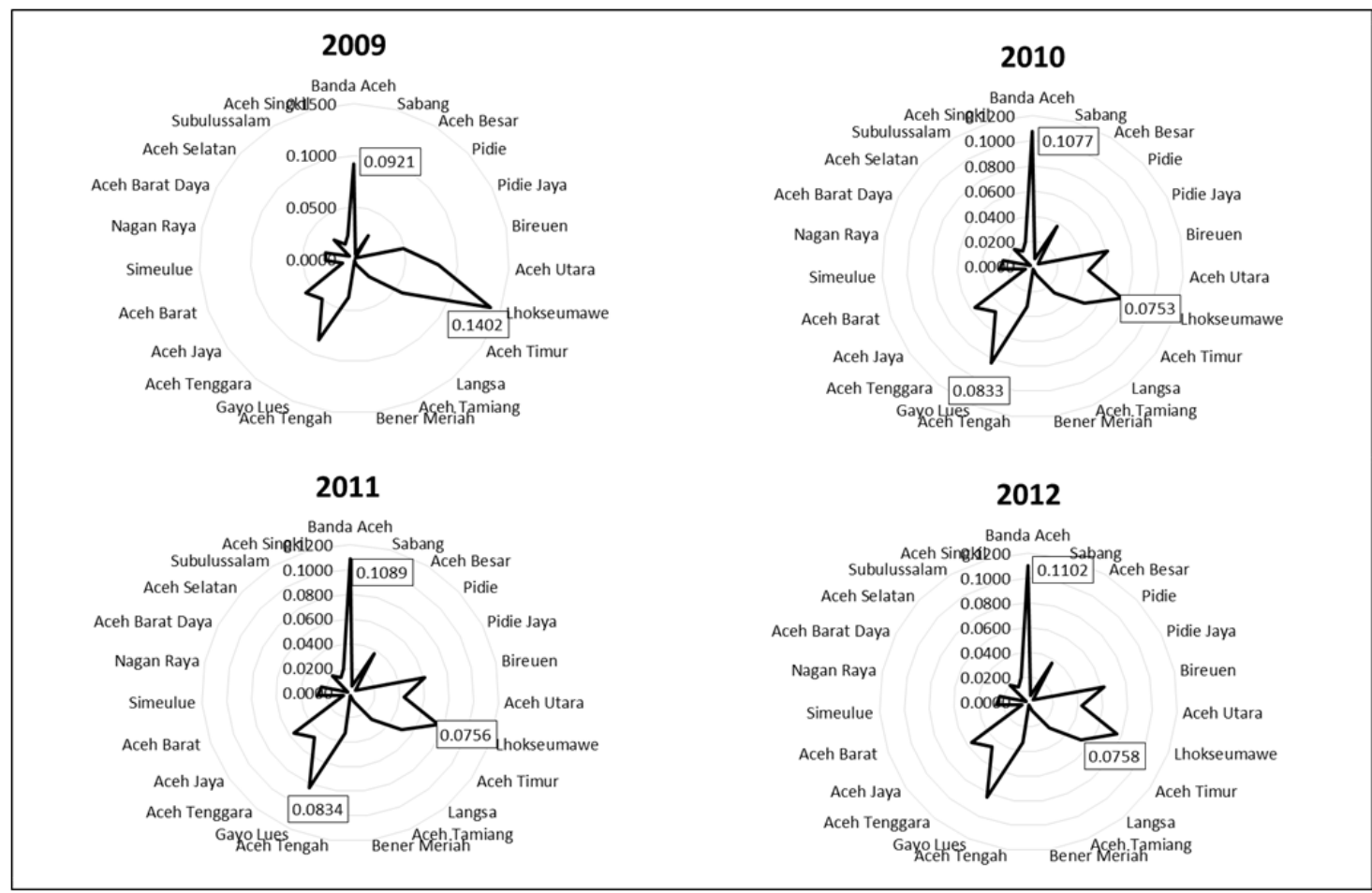

Source: Result of research (2016)

Figure: 2. Patterns of geographical economic concentration 2009 - 2012

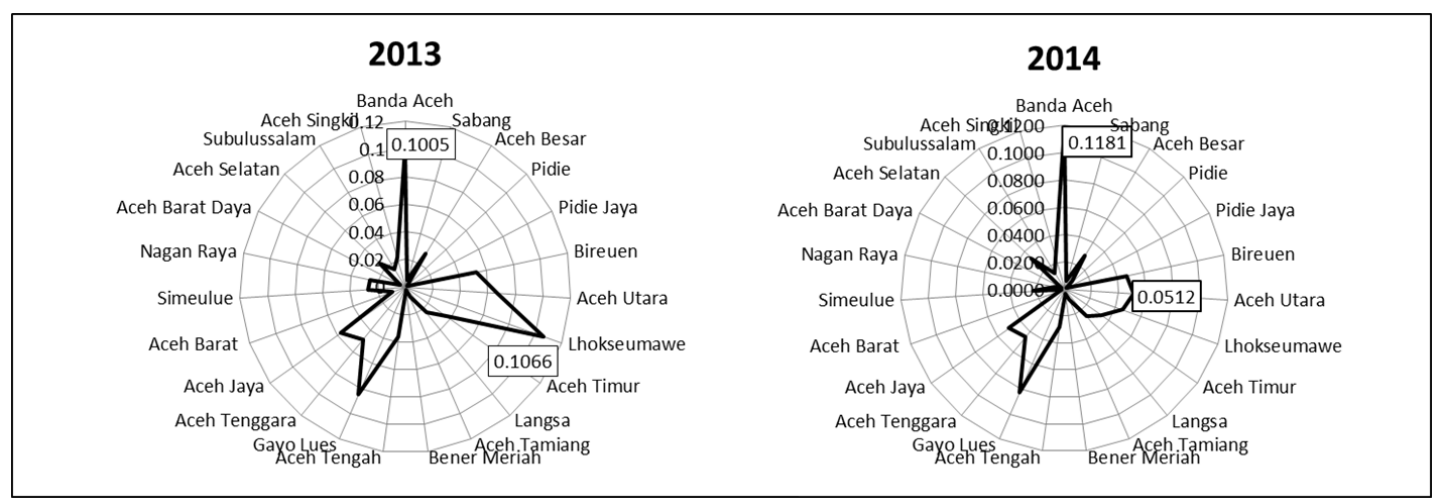

Source: Result of research (2016)

Figure: 3. Patterns of geographical economic concentration $2013-2014$

The geographic concentration changes did not take place in all districts, significantly. It only shifted among North Aceh District, Lhokseumawe City and Banda Aceh City. However, in 2013, economic concentration shifts back from Banda Aceh to Lhokseumawe City with the highest index. This pattern is similar to the year 2009, before the concentration shifted to Banda Aceh. But this condition is still worse than 2009. But this is only temporary condition, because the geographical economic concentration index shifted back to Banda Aceh City in 2014. This is an indication of a shift back from Banda Aceh City to Lhokseumawe City that is shown by the decreasing of concentration index of Banda Aceh City. It describes that the role of non-renewable natural resources in economic 


\section{Jurnal Ekonomi Pembangunan, 18 (2), 2017, 142-158}

development, especially in Aceh, is beginning to end. The districts are no longer possible to rely on those natural resources. North Aceh District experienced that by being exhausted of the natural resources led to decline the economic concentration in the region.
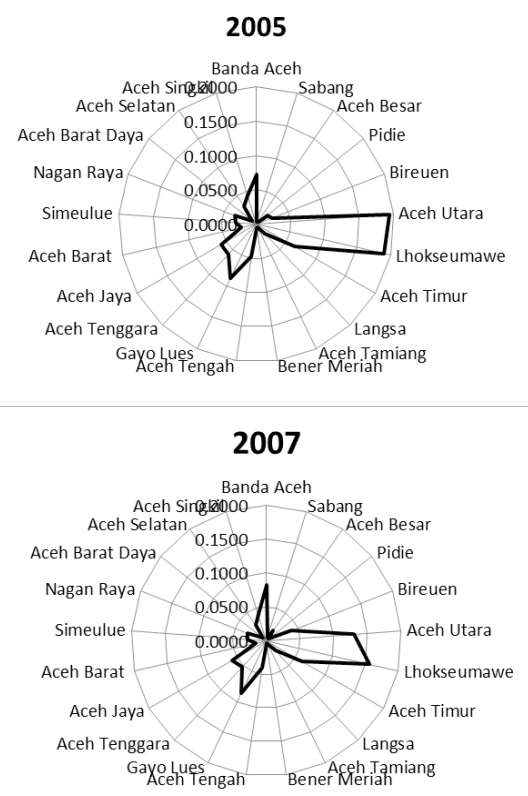

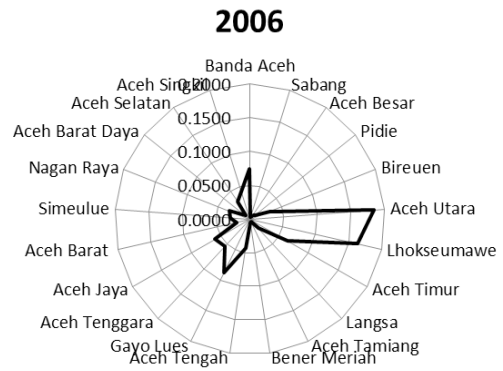

\section{8}

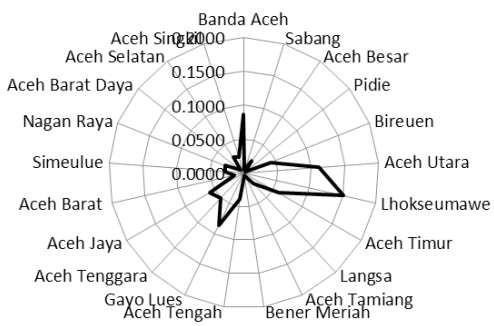

Source: Result of research (2016)

Figure: 4. Patterns of geographical economic concentration 2005 - 2008
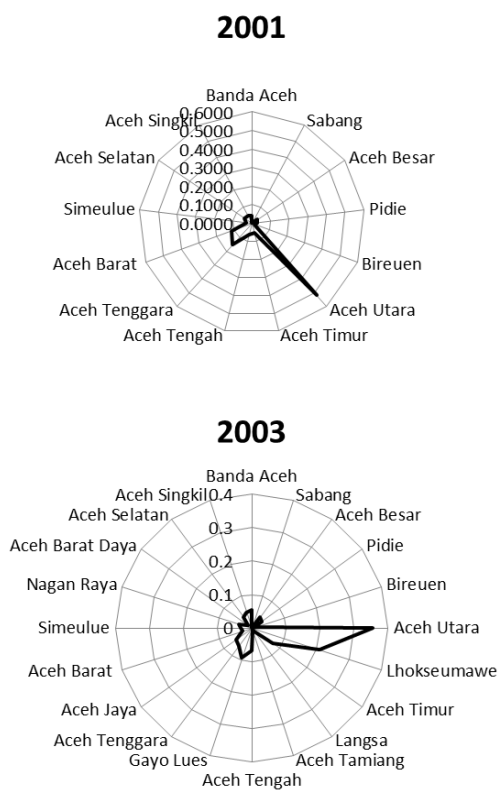

2002
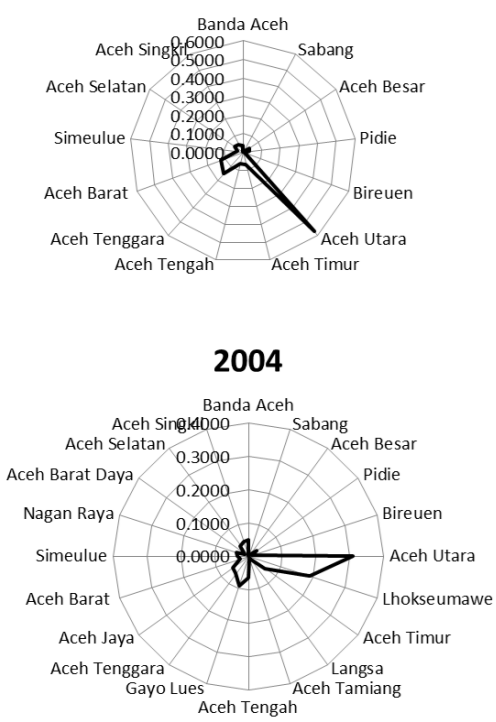

Source: Result of research (2016) 


\section{Jurnal Ekonomi Pembangunan, 18 (2), 2017, 142-158}

In the meantime, there is something unique that Gayo Lues district which is located in the inland area of the Aceh Province. The district has relative high concentration index, but tends to stagnate. This is caused by of not rising up the economic activities as the relatively difficult to reach the region, and as the effect of the limitations of infrastructure. Thus, the development of the region and its economy is very limited. Thus, the economic concentration can occur because of the difficulty of population movements for economic activities geographically. It is similar with the economy in a closed economy. Predictably, if infrastructure and good transportation linking Gayo Lues district with neighboring region, there will be an economic concentration shift to other areas.

There are four phases of geographical economic concentration changes, during 14 years, in Aceh Province, that are:

a. First phase $(2001-2002)$, the highest economic concentration is in North Aceh District. This concentration as a result of the development of the region as an industrial region (primary sector industry). Thus, it became a special attraction for investors, residents and labor forces.

b. Second phase $(2003-2004)$. In this phase, the economic concentration has been divided between North Aceh District and Lhokseumawe City. So, geographical economic concentration index of North Aceh District decreased, then, the economic concentration shifted to Lhokseumawe City.

c. The third phase $(2005-2009)$, the highest concentration was between Lhokseumawe City and North Aceh District. The shift from North Aceh to Lhokseumawe took place, with the decreasing index. Even, in 2009, an indication of a shift in concentration from Lhokseumawe to Banda Aceh began to appear. It is a phenomenon of regions with the potential natural resources or primary sectors have been not significant in economic development. In this period, the big push development occurred in Banda Aceh City as the consequences of rehabilitation and reconstruction program of Aceh post tsunami disaster.

d. The fourth phase $(2010-2014)$, economic concentration was in Banda Aceh City as the main city in Aceh Province. For five years showed the relative same pattern and almost constant index of economic concentration. The highest concentration in Banda Aceh showed the phenomenon of the importance of the role of secondary and tertiary sectors in economic development.

\subsection{Geographical \\ Concentration Analysis}

Jarque-Bera normality test showed the overall data of not distributed normally (Appendix 3b), and significant at $\alpha=0.001$. Then, EGLS (Estimated General Least Square) of panel regression model is used in this analysis. The stochastic unit root test shows that the stationary data are exist at first difference (Appendix 3a). This indicated by all results of LLC as suggested by (Doğan, Volkan, \& Burcu, 2010; Diacon \& Maha, 2015) also see in (Jamal, Muhammad, Masbar, \& Aliasuddin, 2015) are significant at a $=0.01$ and 0.05 . Thus, the panel regression model can be continued.

Result of panel regression by Pooled EGLS, Fixed Effect Model (FEM) and Random Effect Model (REM) are conducted by some tests such as Likelihood Ratio and Hausman Test. The result shows that the REM approach by EGLS is the best choice of this analysis. 
Jurnal Ekonomi Pembangunan, 18 (2), 2017, 142-158

Table: 2. Results of REM

\begin{tabular}{|c|c|c|c|c|c|c|}
\hline \multirow{2}{*}{$\begin{array}{l}\text { Variabel } \\
\text { POPD }\end{array}$} & \multicolumn{2}{|c|}{$\begin{array}{c}\text { Aceh-13 } \\
(2001-2014)\end{array}$} & \multicolumn{2}{|c|}{$\begin{array}{c}\text { Aceh-23 } \\
(2008-2014)\end{array}$} & \multicolumn{2}{|c|}{$\begin{array}{c}\text { Aceh-13 } \\
2001-2007\end{array}$} \\
\hline & $1.50 \mathrm{E}-06$ & & $4.98 \mathrm{E}-06$ & $* *$ & $-1.02 \mathrm{E}-06$ & \\
\hline GECAP & $-1.83 \mathrm{E}-09$ & $* * *$ & $1.54 \mathrm{E}-10$ & & $-3.78 \mathrm{E}-09$ & $*$ \\
\hline SPAGE & $3.47 \mathrm{E}-12$ & * & $-1.21 \mathrm{E}-12$ & & $6.01 \mathrm{E}-12$ & $* * *$ \\
\hline GR & $2.42 \mathrm{E}-05$ & $* * *$ & 0.000574 & $* * *$ & $1.93 \mathrm{E}-05$ & \\
\hline $\operatorname{GEC}(-1)$ & 0.745973 & $* * *$ & 0.890625 & $* * *$ & 0.798746 & $* * *$ \\
\hline Constant & 0.010126 & $* *$ & -0.001120 & & 0.008562 & $* * *$ \\
\hline
\end{tabular}

The results of estimation in Table 2 explains that Aceh-13 in period 2001-2007, prior to the district proliferation massively, SPAGE has a positive sign and very significant, while POPD and GECAP has negative sign, but only GECAP significant statistically. This mean, GECAP led to de-concentration, in other words, GECAP encouraged geographic economic concentrations elsewhere. Actually, the development of concentration of economic geographically elsewhere, will be beneficial to the regions or districts, because the economic development inequality will reduce. But the economic growth (GR) is not significant strongly, although it has positive sign. But this is an indication that economic growth ought to exist.

The positive sign of SPAGE indicates that the density of government spending is an important variable in the early era of district proliferation, so the greater government spending encourages the higher economic activities concentration. However, it encourages politicians to develop their region by proliferation policies as the effects of political decentralization reform in Indonesia. Some researches indicate that massive infrastructure development, particularly transportation infrastructures, lead to increase the economic concentration (Ding, 2013; Turguttopbas, 2016), this is due to the decline of transport cost of firm and investments. In addition, intensive technology development also has a positive relationship to the economic concentration due to increased firm productivity
(Hasan, Faggian, Klaiber, \& Sheldon, 2016). In contrast, (Bertinelli \& Strobl, 2007) states that economic concentrations impact on economic growth, which in turn, the economic will more concentrated. Meanwhile, in periods of 20012014, all variables (GECAP, SPAGE and GR) are significant statistically, exception POPD. This explains that SPAGE and GR encourage increasing economic concentration of the regions. POPD which has positive sign, but not significant statistically, indicates this variable is become more important to perform the economic concentration in this period. In fact, both of variables GECAP and SPAGE, in which before proliferation of regions, SPAGE was more important than GECAP. But, GECAP is more important than SPAGE post proliferation of regions, statistically. However, it can be explained that government expenditure or spending is still play an important role in enhancing the geographical economic concentration in Aceh-13, both per capita and spatially.

On the contrary, in Aceh-23, population density (POPD) and economic growth (GR) become decisive factors for economic concentration, in which both has positive sign and significant statistically. It can be observed that government expenditure, per capita or spatial, no more important here. Economic growth is the most important. But, the low coefficient of POPD is due to the people commuting in economic activities. They work in the new autonomy region, but reside in the parent region. Some districts in Aceh 


\section{Jurnal Ekonomi Pembangunan, 18 (2), 2017, 142-158}

show this phenomenon in population economic activities. The population concentrated in parent district but their activities in new district as result of proliferation. The establishment of home stay of population in the original area or location is difficult to be shifted to other location. Thus, even though the population shifts their economic activities to new district or area, yet they hold to live in the parent district permanently.

This indicates that the population growth and capital formation are the main factors to lead the economic growth, as suggested by neoclassical economics growth model (Fingleton \& Fischer, 2010). Solow model is one of model which was developed and widely accepted (Solow, 1956). On these issues, public policy took a role in developing the economic growth and became the main factor of development of Aceh economy because of the lacks of private investment as the impact of the past vertical conflict in this province, especially in Aceh-13. Thus, the development in all sectors are depended strongly on government budgets both central government budget and local government budget. The productivity of government spending in this issue becomes necessary in decentralized economy in Indonesia. The research conducted by (Carboni \& Medda, 2011) which developed the non-monotonic theoretical concluded that public spending composition is possible to optimize growth in decentralized economy.

Another factor can be observed is the geographical economic concentration of previous period [GEC(-1)]. For all periods and groups, previous period of GEC is strongly significant and positive sign. This indicates that the initial concentration of economic activities is a pacesetter for the later economic concentration. This condition strengthen the statement of (Bertinelli \& Strobl, 2007) above, where economic concentration affects economic growth, further, the economic growth will magnify the economic concentration, hereafter.

Proliferation of districts in Aceh since 2001, in fact, has developed the regions in this case the geographical economic concentration. Thus, local government policies thru the government spending on infrastructure improvement, such as road and bridge infrastructure lead to increase the economic concentration activities, in which, the studies conducted by (Yu, Roo, Jong, \& Storm, 2016) concluded that the road infrastructure has important role in China, it increases economic agglomeration activities. When geographic concentration is low, improvement of road network increases its concentration, but if the concentration is high, reducing the concentration cost drives industries decompose to hinterlands. As the result of research was conducted by (Billings \& Johnson, 2016) which stated that input and output relationship are important to drive industrial agglomeration, so transportation access has positive relationship.

\section{Conclusion}

The result of analysis can be concluded that in period 2001-2014, the geographical economic concentration shifted in four phases, where the concentration shifted from plentiful natural resources district or natural resources based industry region (predominant of villages area) to the district full of secondary and tertiary industrial economic activities which is labeled city. Population density takes important role to increase economic concentration in parent districts (Aceh-13) and post proliferation (Aceh23). But, government spending is no longer a determinant of economic concentration in Aceh post proliferation of districts. On the contrary, before the proliferation process, government spending per capita became the factor of economic de-concentration rather than economic concentration. This condition depicts that government intervention is not important enough to improve economic concentration in the post of proliferation of districts. Otherwise, the effort of enhancing of economics growth becomes the important factor. However, if spatial government spending is raised, it tends to motivate the new 


\section{Jurnal Ekonomi Pembangunan, 18 (2), 2017, 142-158}

economic de-concentration, namely, to perform the new economic concentration. In fact, this condition can reduce regional inequality.

\section{Acknowledgements:}

This research is funded by Ministry of Research, Technology and Higher Education of Republic of Indonesia in 2015. I would like to thank the Directorate of Research and Community Service (DRPM), the Ministry of Research, Technology and Higher Education of the Republic of Indonesia for its support in this research.

\section{References}

Akai, N., Nishimura, Y., \& Sakata, M. (2007). Complementarity, Fiscal Decentralization and Economic Growth. Economics of Governance, 8, 339-362; DOI 10.1007/ s10101-007-0032-5.

Alexiadis, S. (2013). Convergence Clubs and Spatial Externalities: Model and Applications of Regional Convergence in Europe. New York: Springer.

Ascani, A., Crescenzi, R., \& Iammarin, S. (2012, January). New Economic Geography and Economic Integration: A Review. WP1/02 SEARCH WORKING PAPER, pp. 1 - 24; http://www.ub.edu/searchproject/wpcontent/uploads/2012/02/WP-1.2.pdf.

Bautista, A. D. (2003). Mexico's Industrial Engine of Growth: Cointegration and Causality. Momento Economico(126), pp. 34 - 41; http://www.ejournal.unam.mx/moe/no126/ MOE12605.pdf.

Benedek, J. (2016). The Role of Urban Growth Poles in Regional Policy: the Romanian Case. Social and Behavioral Science, 223, 285-290.

Berea, R. C., Otoiu, A., \& Bucerzan, I. (2014). Determinants of economic growth in cities acting as growth poles in regions from Romania. Procedia Economics and Finance, 10, $357-365$.
Bertinelli, L., \& Strobl, E. (2007). Urbanisation, Urban Concentration and Economic Development. Urban Studies, 44(13), 24992510; DOI: 10.1080/00420980701558442.

Billings, S. B., \& Johnson, E. B. (2016). Agglomeration within an Urban Area. Journal of Urban Economics, 91, 13-25; http://dx.doi.org/10.1016/j.jue.2015.11.002.

Bodman, P. (2011). Fiscal Decentralization and Economic Growth in the OECD. Applied Economics, 43, 3021-3035.

BPS. (2016). Statistical Yearbook of Indonesia. Jakarta: BPS-Statistics Indonesia.

Brülhart, M., \& Sbergami, F. (2009). Agglomeration and growth: Cross-country evidence. Journal of Urban Economics, 65, $48-63$.

Cantore, N., Clara, M., \& Soare, C. (2014). Manufacturing as an engine of growth: Which is the best fuel? WORKING PAPER $01 / 2014$.

Carboni, O. A., \& Medda, G. (2011). Government spending and growth in a neoclassical model. Math Finan Econ, 4, 269-285; DOI 10.1007/s11579-011-0045-2.

Castells-Quintana, D. (2015). Malthus living in a slum: urban concentration, infrastructures and economic growth. Working Paper 2015/05; $1 / 31$, p. The Research Institute of Applied Economics (IREA); http://www. ub.edu/irea/working_papers/2015/201506. pdf.

Chen, M., Zhang, H., Liu, W., \& Zhang, W. (2014, August). The Global Pattern of Urbanization and Economic Growth: Evidence from the Last Three Decades. PLOS ONE, 9(8), pp. 1 - 15; http://search.proquest.com/ docview/1551695427textPDF/66BFC88B0D3A4887PQ/9? accountid=38628.

Clipa, R. I., Pohoață, I., \& Clipa, F. (2012). The New Economic Geography and Regional Policy in Romania. Theoretical and Applied 


\section{Jurnal Ekonomi Pembangunan, 18 (2), 2017, 142-158}

Economics, XIX( 8), 5 - 18; http://store. ectap.ro/articole/758.pdf.

Dabla-Norris, E. (2006). The Challenge of Fiscal Decentralisation in Transition Countries. Comparative Economic Studies, 48, 100 131; doi:10.1057/palgrave.ces.8100063.

Diacon, P.-E., \& Maha, L.-G. (2015). The Relationship between Income, Consumption and GDP: A Time Series, Cross-Country Analysis. Procedia Economics and Finance, 23 , 1535-1543; doi: 10.1016/S22125671(15)00374-3.

Ding, C. (2013). Transport Development, Regional Concentration and Economic Growth. Urban Studies, 50(2), 312-328.

Doğan, U., Volkan, A., \& Burcu, G. (2010). The Role of the Economic Size of a Country in Attracting Foreign Direct Investments: A Panel Data Analysis for OECD Countries (1980-2006). Current Research Journal of Economic Theory, 2(1), 1-7.

Duranton, G. (2008). Cities: Engines of Growth and Prosperity for Developing Countries? WORKING PAPER NO. 12 , pp. 1 - 51; http://siteresources. worldbank.org/EXTPREMNET/ Resources/489960-1338997241035/ Growth_Commission_Working_Paper_12_ Cities_Engines_Growth_Prosperity Developing_Countries.pdf.

Ellison, G., \& Glaeser, E. L. (1997). Geographic Concentration in U.S. Manufacturing Industries: A Dartboard Approach. Journal of Political Economy, 105(5), 889-927; http://www.remi.com/uploads/File/Articles/ article_126.pdf.

Fan, C. C., \& Scott, A. J. (2003). Industrial Agglomeration and Development: A Survey of Spatial Economic Issues in East Asia and Statistical Analysis of Chinese Regions. Economic Geography, 295-319.

Fana, S., Kanbur, R., \& Zhang, X. (2011). China's regional disparities: Experience and policy.
Review of Development Finance, 1, 47 - 57.

Fingleton, B., \& Fischer, M. M. (2010). Neoclassical theory versus new economic geography: competing explanations of cross-regional variation in economic development. Ann Reg Sci, 44, 467-491; DOI 10.1007/s00168008-0278-z.

Fujita, M., \& Thisse, J.-F. (2002). Economics of Agglomeration: Cities, Industrial Location, and Regional Growth. Cambridge: Cambridge University Press.

Gardiner, B., Martin, R., \& Tyler, P. (2010). Does spatial agglomeration increase national growth? some evidence from Europe. Journal of Economic Geography, pp. 1 - 28; doi:10.1093/jeg/lbq047.

Grechyna, D. (2016). On the Determinants of Political Polarization. Economics Letters, 144, pp. 10 -14.

Gujarati, D. (2011). Econometrics by Example. London, England: Palgrave MacMillan.

Hammond, G., \& Tosun, M. (2009, November ). The Impact of Local Decentralization on Economic Growth: Evidence from U.S. Counties. IZA Discussion Paper No. 4574.

Harper, T., Hibbard, M., Costa, H., \& Yeh, A. G.O. (2011). Introduction: Rising to the Global Challenges. In M. H.-O. Thomas L. Harper, Dialogues in Urban and (p. 5). New York: Routledge.

Hasan, S., Faggian, A., Klaiber, H. A., \& Sheldon, I. (2016). Agglomeration Economies or Selection? An Analysis of Taiwanese Science Parks. International Regional Science Review, 1-29; DOI: $10.1177 / 0160017616642822$.

Hetherington, M., \& Weiler, J. (2009). Authoritarianism and Polarization in American Politics. Cambridge: Cambridge University Press.

Im, K. S., Pesaran, M. H., \& Shin, Y. (2003). Testing for Unit Roots in Heterogeneous 


\section{Jurnal Ekonomi Pembangunan, 18 (2), 2017, 142-158}

Panels. Journal of Econometrics 115 (2003) $53-74,115,53-74$; http://down.cenet. org.cn/upfile/54/200642720521160.pdf; doi:10.1016/S0304-4076(03)00092-7.

Jamal, A., Muhammad, S., Masbar, R., \& Aliasuddin. (2015). Did Indonesian Political Economic Reform Reduce Economic Growth Disparities Among Region? DLSU Business and Economic Review, 25(1), pp. 81-94.

Kim, S. (2008). Spatial Inequality and Economic Development: Theories, Facts, and Policies. WORKING PAPER NO. 16, p. The World Bank; .

Latzko, D. A. (2013). The Geographic Concentration of Economic Activity across the Eastern United States, 1820 - 2010. Journal of Historical Geography, 41, 68-81.

Levin, A., Lin, C.-F., \& Chu, C.-S. J. (2002). Unit Root Tests in Panel Data: Asymptotic and Finite-sample Properties. Journal of Econometrics, 108, 1-24; http://homepage. ntu.edu.tw/ clin/2002pur.pdf; doi:10.1016/ S0304-4076(01)00098-7.

López-Rodríguez, J., \& Faíña, A. (2007). Regional Wage Disparities in Europe: What role for Market Access? Investigaciones Regionales, 11, 5 - 23; http://www.redalyc. org/pdf/289/28901101.pdf.

MacLachlan, I., \& Sawada, R. (1997, Winter). Measures of income inequality and social polarization in Canadian metropolitan areas. Canadian Geographer, 41(4), pp. 377 - 397.

McCann, P. (2001). Urban and Regional Economics. New York: Oxford University Press.

OECD. (2003, January 13). Geographic Concentration and Territorial Disparity in OECD Countries. Working Paper, pp. http://www.oecd.org/governance/regionalpolicy/15179757.DOC; Access: March 2, 2011.
O'Sullivan, A. (2007). Urban Economics (Sixth Edition ed.). New York: McGrawHill.

Persky, J., Felsenstein, D., \& Carlson, V. (2004). Does "Trickle Down" Work?, Economic Development Strategies and Job Chains in Local Labor Markets. Michigan: W.E. Upjohn Institute for Employment Research.

Pons-Novell, J., \& Viladecans-Marsal, E. (1999). Kaldor's Laws and Spatial Dependence: Evidence for the European Regions. Regional Studies, 33(5), pp. 443 - 451; http:// citeseerx.ist.psu.edu/viewdoc/download?doi=10.1.1.465.2820\&rep=rep1\&type=pdf.

Rutkevich, M. N. (1994). Social polarization. Russian Social Science Review, 35(1), pp. 12 - 35; DOI:10.2753/RSS1061-1428350112.

Solow, R. M. (1956, February). A Contribution to the Theory of Economic Growth. The Quarterly Journal of Economics, 70(1), 6594.

Spiezia, V. (2002). Geographic Concentration of Production and Unemployment in OECD Countries. http://www.oecd.org/ dataoecd/43/0/15179780.doc; Access: April 15,2011 .

Su, D., \& Yao, Y. (2016). Manufacturing as the Key Engine of Economic Growth for MiddleIncome Economies. ADBI Working Paper Series No. 573, Asian Development Bank Institute; http://www.adb.org/sites/default/ files/publication/184350/adbi-wp573.pdf.

Szirmai, A., \& Verspagen, B. (2010). Is Manufacturing Still an Engine of Growth in Developing Countries? Paper Prepared for the 31st General Conference of The International Association for Research in Income and Wealth, http://www.iariw.org/ papers/2010/6cSzirmai.pdf.

Talmaciu, M. (2012). Considerations Regarding the Development of Romanian Regional Economies through Innovation and Entrepreneurship. Procedia Economics and Finance, 3, 914 - 920. 
Jurnal Ekonomi Pembangunan, 18 (2), 2017, 142-158

Turguttopbas, N. (2016). Regional Development and Logistic Centrers: A Turkish Experience. Perspective of Innovations, Economics and Business, 16(2), 89-103; http://dx.doi.org/10.15208/pieb.2016.07.

Vertakovaa, Y., Polozhentseva, Y., \& Klevtsova, M. (2015). The Formation of the Propulsive Industries of Economic Development Acting as the Growth Poles of Regions. Procedia Economics and Finance(24), pp. 750 - 759.

Waverman, L. (2015). Polarization of Job Losses: Canada and the USA, the Role of ICT. Digiworld Economic Journal, 100(4; ProQuest), pp. 165 - 212.

Yu, N., Roo, G., Jong, M., \& Storm, S. (2016). Does the Expansion of a Motorway Network lead to Economic Agglomeration? Evidence from
China.TransportPolicy, 45, 218-227; https:// doi.org/10.1016/j.tranpol.2015.03.014.

Yushkov, A. (2015). Fiscal decentralization and regional economic growth: Theory, empirics, and the Russian experience. Russian Journal of Economics, 1, 404 - 418.

Zheng, X., \& Liu, Z. (2010). A Study on the Impact of Industrial Concentration on the Economic Growth Based on the Analysis of Gini Coefficient of the Constrution Regions. Applied Mechanics and Materials, 29 - 32, pp. 2703 - 2708; http://search.proquest.com/ docview/1443790060/fulltextPDF/66BFC88B0D3A4887PQ/1?accountid=38628. 
Jurnal Ekonomi Pembangunan, 18 (2), 2017, 142-158

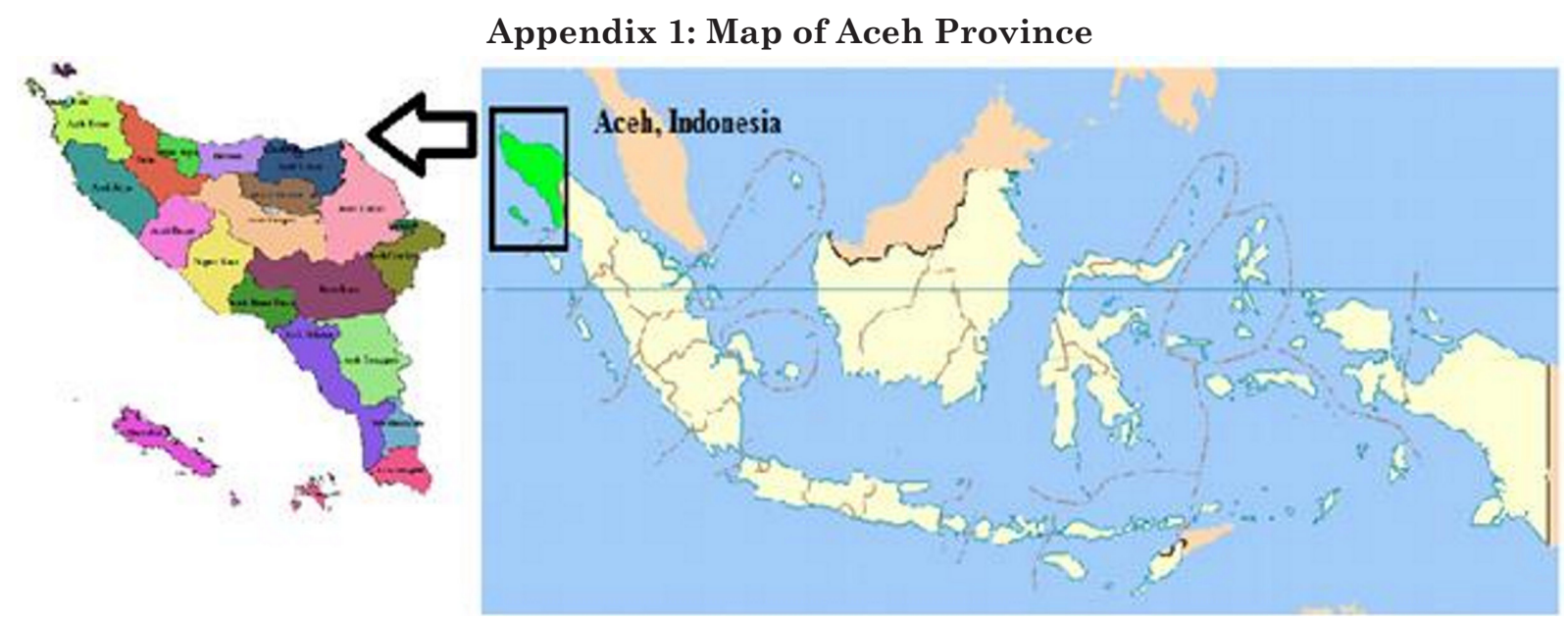

Source: (Jamal, Muhammad, Masbar, \& Aliasuddin, 2015).

Appendix 2: Aceh-13 and Aceh-23

\begin{tabular}{|c|c|c|c|}
\hline No & Aceh-13 (Initial Regions) & No & $\begin{array}{c}\text { Aceh-23 (Initial and New Autonomous Regions) } \\
\text { as the result of proliferation of districts }\end{array}$ \\
\hline 1. & Sabang City & 1. & Sabang City \\
\hline 2. & Banda Aceh City & 2. & Banda Aceh City \\
\hline 3. & Aceh Besar (Great Aceh) & 3. & Aceh Besar (Great Aceh) \\
\hline \multirow[t]{2}{*}{4.} & Pidie & 4. & Pidie \\
\hline & & 5. & Pidie Jaya \\
\hline \multirow[t]{2}{*}{5.} & Aceh Utara (North Aceh) & 6. & Aceh Utara (North Aceh) \\
\hline & & 7. & Lhokseumawe City \\
\hline 6. & Bireuen & 8. & Bireuen \\
\hline \multirow[t]{3}{*}{7.} & Aceh Timur (East Aceh) & 9. & Aceh Timur (East Aceh) \\
\hline & & 10. & Langsa City \\
\hline & & 11. & Aceh Tamiang \\
\hline \multirow[t]{2}{*}{8.} & Aceh Tengah (Central Aceh) & 12. & Aceh Tengah (Central Aceh) \\
\hline & & 13. & Bener Meriah \\
\hline \multirow[t]{2}{*}{9} & Aceh Tenggara (South-East Aceh) & 14. & Aceh Tenggara (South-East Aceh) \\
\hline & & 15. & Gayo Lues \\
\hline \multirow[t]{2}{*}{10.} & Aceh Barat (West Aceh) & 16. & Aceh Barat (West Aceh) \\
\hline & & 17. & Aceh Jaya \\
\hline \multirow[t]{2}{*}{11.} & Simeulue & 18. & Simeulue \\
\hline & & 19 & Nagan Raya \\
\hline \multirow[t]{3}{*}{12.} & Aceh Selatan (South Aceh) & 20. & Aceh Selatan (South Aceh) \\
\hline & & 21. & Aceh Barat Daya (South-West Aceh) \\
\hline & & 22. & Subulussalam City \\
\hline 13. & Aceh Singkil & 23. & Aceh Singkil \\
\hline
\end{tabular}


Avalaible online at http://journals.ums.ac.id, Permalink/DOI: 10.23917/jep.v18i2.2786

Jurnal Ekonomi Pembangunan, 18 (2), 2017, 142-158

Appendix 3a: Unit root test

\begin{tabular}{llccc}
\hline \multirow{2}{*}{ Variable } & \multicolumn{4}{c}{ Aceh-23 } \\
\cline { 2 - 5 } & \cline { 2 - 5 } & LLC & At Level & \multicolumn{1}{c}{$1^{\text {st }}$ Different } \\
\hline KG & -3.62023 & 0.0001 & -24.6317 & 0.0000 \\
POPD & -10.8336 & 0.0000 & -22.4328 & 0.0000 \\
GEKAP & -1.55320 & 0.0602 & -12.3658 & 0.0000 \\
SPAGE & -0.40087 & 0.3443 & -96.4576 & 0.0000 \\
GR & -6.74369 & 0.0000 & -15.3688 & 0.0000 \\
\hline
\end{tabular}

\begin{tabular}{llclc}
\hline \multirow{2}{*}{ Variable } & \multicolumn{4}{c}{ Aceh-13 (2001-2014) } \\
\cline { 2 - 5 } & \multicolumn{3}{c}{ At Level } & \multicolumn{2}{c}{$1^{\text {st }}$ Different } \\
\cline { 2 - 5 } & LLC & Prob & LLC & Prob \\
\hline KG & -5.63325 & 0.0000 & -16.2621 & 0.0000 \\
POPD & -3.32797 & 0.0004 & -11.9375 & 0.0000 \\
GEKAP & 3.19566 & 0.9993 & -4.47429 & 0.0000 \\
SPAGE & 6.64665 & 1.0000 & -1.95864 & 0.0251 \\
GR & -80.4465 & 0.0000 & -16.0754 & 0.0000 \\
\hline
\end{tabular}

\begin{tabular}{lllll} 
GR & -80.4465 & 0.0000 & -16.0754 & 0.0000 \\
\hline \multirow{2}{*}{ Variable } & \multicolumn{4}{c}{ Aceh-13 } \\
\cline { 2 - 5 } & \multicolumn{4}{c}{ At Level } \\
\cline { 2 - 5 } & LLC & Prob & LLC & Prob \\
\hline KG & 0.70092 & 0.7583 & -9.90886 & 0.0000 \\
\hline POPD & -3.72464 & 0.0001 & -7.79747 & 0.0000 \\
\hline GEKAP & -8.90519 & 0.0000 & -10.4498 & 0.0000 \\
\hline SPAGE & -2.11002 & 0.0174 & -8.10633 & 0.0000 \\
\hline GR & -7.96689 & 0.0000 & -11.8598 & 0.0000 \\
\hline
\end{tabular}

Appendix 3b: The Normality test

\begin{tabular}{|c|c|c|c|}
\hline \multirow{2}{*}{ Variable } & \multicolumn{3}{|c|}{ JB Test } \\
\hline & Aceh-23 (2008-2014) & Aceh-13 (2001-2014) & Aceh-13 (2001-2007) \\
\hline GEC & $55.105^{* * *}$ & $5283.675 * * *$ & $1196.8540 * * *$ \\
\hline POPD & $2032.774^{* * *}$ & $869.776 * * *$ & $465.1413 * * *$ \\
\hline GECAP & $251.589 * * *$ & $697.574 * * *$ & $167.1763 * * *$ \\
\hline SPAGE & $5781.565^{* * *}$ & $4411.616 * * *$ & $1163.7390 * * *$ \\
\hline GR & $10426.370^{* * *}$ & $55194.340 * * *$ & $7767.7520 * * *$ \\
\hline
\end{tabular}

